\title{
Pachucos, Chicano Homeboys and Gypsy Caló: Transmission of a Speech Style
}

\section{MaryEllen Garcia University of Texas at San Antonio}

The term caló is well-known within many Mexican American communities as a bilingual slang that is one of several speech styles in the community repertoire, closely associated with Pachuco groups of the U.S. Southwest that came to prominence in the 1940's. But the term calo predates its introduction to the U.S. by many decades. With roots in a Romany-based germanía of the $16^{\text {th }}$ century, from the speech of immigrant gypsies evolved a new Spanish-based argot, the result of language shift from Romany to Spanish over centuries. By the $19^{\text {th }}$ century, caló referred to a Spanish-based criminal argot called "caló jergal" by a contemporaneous Spanish researcher (Salillas 1896), a mixed code of gypsy Romany and Peninsular Spanish which was used by members of that group as an in-group, secret speech style.

This type of secret code, retaining some of the gypsies' Sanskrit-origin words and characteristic wordplay, may still be found in use among some of the Spanish-speaking 
criminal populations in Spain and in the Americas. Moreover, gypsies are still an identifiable ethnic presence in Spain, and some features of gypsy caló are found in the vernacular Spanish slang of some cities like Madrid (Oliver 1987) and Malaga (Cipas 1973). That elements of gypsy caló are still found in the dialects of Spain is not surprising; what is, however, is its relationship to the in-group argot of the Mexican American Pachucos of the early decades of the $20^{\text {th }}$ century in the United States. From available historical evidence, the Pachucos appear to have spoken in the same creative, neologistic style as did the Spanish gypsies, where elements of Pachuco caló were subsequently incorporated into the slang of the Spanish-speaking communities of which they were a part, similar to what happened in some parts of Spain. Moreover, words of gypsy origin are still found in the speech of modern day Chicano youths, some of them the "homeboy" lingo used by street gangs, despite the fact that many members of this younger generation do not speak Spanish. What explains the transmission of a longago gypsy speech style to new groups on a new continent? What elements of this style were appropriated by the community at large and why?

Questions regarding the interrelationship between and among ethnic minorities are rarely addressed in ethnic studies research. When linguistic evidence of connectedness surfaces, the question that emerges is whether marginalized groups transmit their covert cultural and linguistic practices not only across ethnic groups but across time as well. While the influence of Romany germanía, an in-group criminal argot, on other criminal jargons in Europe and in Latin America is generally assumed to have gone hand-in-hand with the incursions of the nomadic Rom, i.e., the Romany peopleself-labeled as "gypsies"-into these areas, assumptions about the transmission of this way of speaking have, to my knowledge, never been questioned nor fully explored. In order to provide a satisfactory explanation 
for the similarity of the argots across time and space we must make explicit links between the intra- and intergroup lifestyles of the groups, their social and economic marginality, and their linguistic practices. The primary purpose of the current study is to examine two issues: one, the transmission of a speech style from the Old World to the New, given that what is transmitted is an "insider" style of speech, a social dialect rather than a regional one; and two, the iconization of the caló speech style as a marker of a bilingual Chicano or Mexican American identity by members of the community at large, first in the era of the Pachucos and persisting to the present day.

\section{Communities of practice}

The conceptual background of this research is that articulated by Eckert and McConnell-Ginet (1992; 1995) in investigating language and gender. Their sociolinguistic-anthropological approach is based on the notion of "communities of practice," groups through which individuals move and "belong to" based on a constellation of beliefs and behaviors, not the least of which is language. In their words, "Language is a primary tool people use in constituting themselves and others as "kinds" of people in terms of which attributes, activities, and participation in social practice can be regulated... how people talk expresses their affiliations with some and their distancing from others, their embrace of certain social practices and their rejection of otherstheir claim to membership (and to particular forms of membership) in certain communities of practice and not others" (Eckert \& McConnell-Ginet 1995, 470).

Mobility has also been discussed as a potentially important but little-studied correlate of linguistic behavior; although it has been recognized only indirectly in discussions of social class (see discussion in Chambers 1995, 57). It is of interest to note that the particular types of communities of practice under discussion are of limited social mobility, or at least their members have 
perceived themselves as such. It is the perception of lack of mobility, perhaps, rather than the actual potential that motivates behaviors antithetical to the typical working, middle, and other classes who conform to mainstream ideologies. The groups under discussion here are arguably both ethnically and economically marginalized, and their own actions in response to this state of affairs may have contributed and continue to contribute to their social marginalization. Clearly, class could be considered a relevant social variable in characterizing them, but it is perhaps the perceived lack of social mobility that leads to the lifestyles shared by these communities of practice.

\section{Marginalized communities}

The particular communities of practice whose language is of interest are the following: a) the criminal element in the Spain of the late $19^{\text {th }}$ century, whose caló jergal "gypsy slang" is documented to have originated in gypsy cant (Salillas 1986); b) youth groups in Mexico that have similar lifestyle and speech characteristics (Alarcón 1978); c) the Pachuco groups of the 1930's and 40's in the US, in which Mexican American youths expressed their bilingual/bicultural identity (Barker 1975; Webb 1976, 1982) ; and d) contemporary Chicano youths, particularly those in Los Angeles and in South Texas, identified by researchers as belonging to gangs (Vigil 1988; Moore 1978; Valdez, et. al. 1999). Each successive group appears to be the descendant of the previous one socially, linguistically, and historically. What the latter three groups have in common are their youth and emerging adult identity, their defiance of authority, their marginalization in the society, and their Spanish-background cultural heritage and language. The following discussion of the lifestyles of all four groups does not seek to perpetuate stereotypes, but merely reports what other scholars have said to be typical of them.

The origin of calo in the gypsy culture of Spain was the Romany contact dialect with Spanish known as germanía, 
a synonym for hermandad or "brotherhood." Immigrating to Spain and the rest of Europe in the $15^{\text {th }}$ century, the Romany people used a special language that originated in their lifestyle, which was often defiant of the laws established by the middle- and upper-classes of the time. Dark-haired and dark-skinned, the group was different in appearance and mode of dress from the societies they came into contact with at the time of their diaspora. They were itinerants for a long time, living on the margin by any means they could, but by the late $19^{\text {th }}$ century they had become a stable population in Andalusia, particularly Seville (Stewart 1992, 24). The tradition of not intermarrying outside of their ethnic group, their beliefs in the supernatural, the strong division of gender roles in the culture, their allegiance to their own judicial code and their widespread reputation as thieves and liars-well-founded or not-have kept them on the margins of Spanish society (Stewart 1992; Chaliand and Ragean 1995).

Whether similar lifestyles in the New World existed at the time cannot be known with certainty. However, the linguistic similarities of the calo of Andalusia and that of the New World strongly suggest direct contact with the gypsies of Spain. It is possible that the argot was transmitted to pre-existing groups in America that were already socially marginalized, had limited means of support, and had an ethical code that defied the laws of conventional society. If we accept the idea of pre-existing, parallel communities of practice, it is not difficult to explain the transmission of caló to other groups in the Americas.

\section{The temporal-spatial link}

The historical connection between the Old World gypsies and the New World youth gangs may have been gypsy bullfighters who interfaced with the drug scene of Mexico City (Vigil 1988: 6; Barker 1975:191), likely in the early $20^{\text {th }}$ century. The caló speech style may have 
been extremely functional for both groups for the same reasons, namely to hide questionable activities. Such contact with marginalized groups in Mexico City would account for the existence of a variety of caló spoken by some youth groups who follow similar lifestyles in that city to the present day. In the late 20th century Alarcón (1978) investigated the speech of adolescents and older jóvenes or 'youth' in the Mexican capital, recognizing its origins in the speech of criminals.

Dentro de los subgrupos sociales en los que podemos encontrar el empleo de jergas específicas, se encuentra el de los delincuentes cuyo conjunto de elementos léxicos y sintácticos ha sido conocido como germanía (del latín germanus, hermano), y, actualmente como caló o argot. Es un lenguaje de convención imaginado por los ladrones, pícaros y vagabundos de una sociedad, y es un fenómeno que se presenta fundamentalmente en las ciudades... $(1978,48)$

[Within the social subgroups in which we can find the employment of specific slang varieties, we find that of delinquents whose set of lexical and syntactic elements has been known as germanía (fromLatin germanus, 'brother') and is now called caló or argot. It's a language of convention created by the thieves, scoundrels and tramps of a society, and it is a phenonomenon that presents itself fundamentally in cities.]

Alarcón also reports that this type of argot was as likely to be spoken by jóvenes of the upper social classes masquerading as the working classes because of its authenticating, i.e. reverse snob, appeal (Alarcón 1978, 100-103). Assuming Mexico City to be the primary locus of contact in North America, it is not difficult to believe that the adoption of the caló speech style by certain 
Mexican American youths in El Paso occurred as the result of interaction with a similar community of practice, i.e., the drug subculture. The fact that it is reported to have been used also by the young men of the community during World War I (Coltharp 1965, 30) as an "inoffensive" jargon hints at the covert prestige that it must have held for those outside of the initial in-group, as it seems to have done for youths in Mexico City.

Barker $(1975,190-193)$ is the most informative source for the trajectory of calo to the West Coast. Barker indicates that caló was used by the "the Mexican underworld" prior to being adopted in the 1930's by the members of El Paso's “7-X gang, a group of marijuana smokers and peddlers..." (Barker1975:191). He reports that from El Paso it was carried by Mexican American youths who rode the railcars along the route West to Tucson, where some stopped to work in a local bakery. This was independently corroborated by a native of Tucson, Lalo Guerrero (personal interview, July 2000) whose contact with them at the bakery gave him a linguistic basis for a few of his songs and was also one of Barker's original consultants. From Tucson it spread to Los Angeles in the late 1930's and early 1940's by the young men who continued West on the railcars. Largely from El Paso, wordplay on the city's name caused them to be known as Pachucos (García 2005).

The presence of these young men was felt in Los Angeles not long after their arrival. Pachuco youths were said to be the force behind the creation of 40 to 50 juvenile gangs in Los Angeles in the 1940's (Pagan 1996, 8 ). The Pachucos were characterized as having a distinct manner of dress, hairstyle, tattoo markings, and "arcane language," which associated them with merchants dealing in vice (Pagan 1996, 9). In the opinion of some authorities of the time, they formed a network dealing in drugs, theft, and prostitution (Pagan 1996, 9). It should be noted, however, that most Mexican American adolescents and teenagers of the period in Los Angeles and elsewhere did 
not share this Pachuco lifestyle, although the Pachuco in the abstract became an important cultural and linguistic influence on them. Many young men imitated their style of exaggerated dress for social occasions (McWilliams 1968, 242) embodied in the 'zoot suit'-a loose-fitting frock coat, draped pants pleated at the waist and tapered at the hem, often accessorized with a draped watch chain tucked into a vest and a "tando," a flat, narrow-brimmed hat. This manner of dress was not unlike that worn by well-known African American jazz musicians of the time, who were also innovative creators of contemporary slang. The linguistic influence of the Pachuco on the Mexican American teens of the period may account for its currency in the linguistic repertoire of the present-day community and will be discussed further below.

\section{Socio-psychological characteristics}

Barker's fieldwork in Tucson in the 1940's revealed that Pachucos did not feel themselves to be part of American society due to their bilingualism and Mexican heritage. Instead, what was expressed was a desire to look for acceptance by one's own friends (or carnales) as co-conspirators outside the mainstream “... to get what they want from society without having to suffer its penalties." Not deterred by conventional morals, petty theft was acceptable as long as they were not caught. The company of girls was to be enjoyed, but with no strings attached (Barker 1975, 200).

From interviews with older men who were speakers of Pachuco caló as youths, Webb (1982) corroborates their sense of anomie or "namelessness" which came from a lack of identification with their heritage language and culture, Spanish, or with their adopted language and culture, English (Webb 1982, 121). Usually second generation and bilingual in English and Spanish, they had typically been unsuccessful in the English-speaking mainstream and rejected mainstream values. Their shared social, linguistic, cultural and psychological bonds 
were the basis for a peer-group identity, clearly reflected in and expressed by their bilingual argot that combined English and Spanish. It was also called caló after its gypsy origins (see Webb 1975, 124-6 for discussion).

The lifestyle of these groups of young men has apparently not changed significantly over the years. Writing about the general characteristics of Mexican American gangs from the 1940's through the 1970's, Moore observes:

[T] he youth gang is a specialized structure of the barrio, and like any other specialized structure (such as the neighborhood church), it develops a specialized subculture, a set of values, norms, and specialized traditions, and sources of status honor... the adolescent gang is a semisecret organization of adolescents and... in later life may be involved in illegal economic activities." (Moore 1978, 36)

Contemporary researchers also recognize the link between the traditional Pachuco and the newer Mexican American gangs in that they have a distinctive style of dress, i.e. baggy pants, flannel shirts, white muscle shirts, head bandanas (for males), and tattoos (Galindo 1999, 178). Nowadays, those embodying formerly Pachuco styles are referred to as cholos or cholas in some Spanishspeaking communities, or, in areas where the language shift is all but complete, they may be called "chukes" or even "homeboys" and "homegirls," as they are in African American communities.

To summarize, these communities of practice all appear to be closed societies with self-perceptions of limited social mobility, who have distinctive ways of dress and behavior with their own value system and honor code. Furthermore, they are associated with criminal behavior not accepted by conventional society. The use of a distinctive linguistic style, whether it is called caló, pachuco talk, or simply slang between other in- 
group members, is one of the distinctive behaviors that constitute group membership.

\section{Speech style and identity}

Researchers of both caló and pachuco indicate that the principal reason for their creation and continued use was to hide criminal activity from out-group members, such as police or law-abiding citizens. True caló is used as a secret code to hide illegal activities, a function which goes back to its earliest manifestations. According to Barrow, the "robber language" of the $19^{\text {th }}$ century criminal groups in Europe was used by thieves to "...discuss their schemes and plans of plunder, without being [sic] in general understood by those to whom they are obnoxious" (1843:336).

In a similar vein, Alarcón says of twentieth century Mexico City caló carcelario, i.e., the argot of jail inmates:

Estas lenguas gregales [jergales?] tienen su principio básico en disfrazar los significados directos, para el no entendimiento de las demás personas . . . (Alarcón 1978:100) [These slangy tongues have their basic origin in disguising direct meanings so that other people don't understand [them]...

Barker, studying the use of caló in Tucson in the 1940 's, identified it as a Pachuco argot, "a cant or class jargon," which, because it was bilingual, was "a hybrid arising from a mixture of languages" $(1975,183)$. He characterized its speakers as being “...adolescents and young men of Mexican descent" of the working class, situated in west Tucson during that period $(1975,185)$. While not all speakers of Pachuco were gang members in his estimation, those who were differed from those who were not because "...gang participants speak [P]achuco habitually, as a means of communication, and ...gang members have a larger and more up-to-date vocabulary than nonparticipants" $(1975,199)$. 
Modern-day Chicano gang members maintain the function of caló as a secret code or speech style. According to Vigil's study of Los Angeles gang life (1988, 119), youths shifted their manner of speaking when law enforcement and criminal justice authorities appeared, as if to protect each other from the "... intrusions of untrustworthy strangers" (Vigil 1998, 119). However, in modern-day Los Angeles, language shift has meant limitations in their use of Spanish.

Today barrio gang talk is mostly English, and the degree of Spanish and cholo terms that are spoken is dependent on the tradition and generational history of the barrio; in a fashion, it is one way to show loyalty and allegiance to remnants of Mexican culture, or, more basically, "us" against "them". (Vigil 1988,119)

Of course, caló does not function merely to hide ingroup communication from outsiders, but also functions as a manifestation of the social solidarity of alienated ethnic youth.

At perhaps the deepest level, caló borders on and blends with delinquent cant and, though often used specifically to screen out those persons who do not share the values of extralegal life, still also serves to promote deflation of dignity, nonconventionality, group intimacy, status recognition, or all of these. (Webb 1975, 124-5)

Along with the social and behavioral similarities across these communities, those who belong to them use caló as a way of performing their identity as members of the ingroup. In the words of one Chicana researcher concerning two Mexican American women who were participants in that lifesyle in Texas: 
The adaptation of these linguistic codes [caló and taboo language] symbolized personal empowerment and assertiveness, affirmation of in-group membership, and the antithesis of silence and repression as they recounted experiences of pachuca activity, buying / selling/using drugs, and prison life. (Galindo 1999, 177)

Borrow observed that the Romany-based gypsy cant had become the basis for othercriminal jargons in Europe, including the Spanish-based caló (1843, 332). Earlier discussions considered varieties of caló to be secret "languages" or special "codes". However, as Coltharp pointed out for the Mexican American variety, "It uses, basically, the syntax of Spanish modified only in isolated instances by English syntax. The affixes and paradigms are Spanish. It cannot be called a 'language'” $(1965,77)$. The main differences of these Spanish speech styles from the more widely-understood vernacular were not their core grammar underpinnings, but their lexical elements, through which meaning was regularly obfuscated via a variety of means.

In previous research on caló the emphasis placed on the creative use of language to reinforce the socially defiant, non-mainstream identity of the group is unmistakable. It is likely that these groups were and continue to be highly multiplex, tightly integrated, social networks of the type discussed by Milroy as "the sum of relationships which he or she has contracted with others" $(1987,105)$. As she elaborates:

This means that if an individual is embedded in such a network, $\mathrm{s} /$ he is more liable than one whose network is relatively loose-knit to be vulnerable to pressure exerted by everyday social contacts. This pressure may result in the maintenance of a set of norms-including linguistic norms---which then flourish in opposition to publicly legitimized norms. (Milroy 1987, 106) 
Not only do the neologistic argot and taboo words create barriers of understanding and thereby symbolically reject publicly sanctioned registers, but the bilingual code in itself exhibits a rejection of the common mainstream norm of using one language at a time, one example of the "legitimized norms" mentioned by Milroy. The speech style is an iconization of the lifestyle, defiant of many mainstream norms and therefore symbolic of the group.

With Spanish providing the functional morphology, syntax and cohesion markers, speakers of these varieties are free to manipulate lexicon in order to at once obfuscate their meanings from the un-initiated and the unwelcomed and to mark their status as in-group members. The neologistic word-creations that melded English and Spanish, like taiya over corbata for "tie," the nonsense extension of the affirmative si to create Simón, as well as the shortening of known words like pantas from pantalones, all flew in the face of established norms of a monolingual Spanish language community to uniquely mark an ethnic identity that was neither completely Mexican nor completely American. Also included as part of the repertoire were terms that were typically of unknown origin to these speakers, but widely used, or at least widely-understood, such as bato to mean hombre, "man," or calcos to mean zapatos, "shoes"both traceable to the gitano caló jergal, or gypsy ingroup slang, documented by Salillas (1896) as serving the undeniable if unconscious function of linking the two marginalized groups. The Pachuco speech style, which shuts out monolingual English and Spanish speakers alike, can be viewed as providing a cultural bond for Mexican Americans, who were often reprimanded for speaking Spanish at school, for not speaking "proper" Spanish and were subsequently denied schooling, housing and job opportunities in the United States Southwest at midcentury.

Linguistic style has been characterized by Eckert as "a clustering of linguistic resources, and an association 
of that clustering with social meaning..." $(2001,123)$. The symbolic relationship between speech and identity has also been deemed "iconization" (Irvine 2001, 33), which the researcher labels "a semiotic process that transforms the sign relationship between linguistic features and the social images to which they are linked." Coupland (2001) presents a comprehensive discussion of style which distinguishes the perspective of autonomous sociolinguistics from a more fluid characterization. In terms of conventional sociolinguistics, style is a 'situational correlate' (187), determined by the social situation in which speech occurs. His preferred perspective is one that explores the role of style in "... projecting speakers' often-complex identities and in defining social relationships and other configurations of context" (186). In keeping with the second of these characterizations, the relationship between speech style and symbolic social meaning is clear for users of caló. That is, caló serves as a speech style that represents a constellation of behaviors shared by this type of marginalized youth group and so it is at once an iconization of its lifestyle and a symbolic expression of its attitudes toward the mainstream. For speakers in the greater Mexican American community who still know and use some of the traditional calo words and expressions, it is symbolic of their identity as bilingual, bicultural individuals and thus an iconization of the community's historical ethnic and linguistic oppression.

\section{The caló of Hispanic Youths in South Texas}

It is not surprising that the linguistic study of caló speakers in the past yielded numerous lexical studies, glossaries, and dictionaries (e.g., Borrow 1843; Salillas 1896; Wagner 1955; Webb 1976\& 1982). The speech variety of each locale-Andalucía, México, the Southwestern United States-appear to have various lexical categories in common, such as: a) the retention of traditional terms, i.e., of germanía in Andalucía and of gitano caló in the U.S., b) neologisms, new words created by blending two 
languages or simply by morphological manipulation of a root word, and c) semantic or syntactic calques from the contact language. Also typical of such jergas or argots is the frequent use of taboo expressions, which serve as blatant violations of conventional norms of speech. A more extensive discussion of the linguistic characteristics of gitano and Pachuco caló is presented elsewhere in detail (García 2005) and will not be repeated here. (However, see Appendices A and B for discourse segments of gitano caló and Pachuco caló from other published sources.)

The data used here to exemplify modern day caló were taken from interviews done with members of Hispanic gang members as part as part of a study by university colleagues on gang drug usage and gang drug dealing in South Texas (see Yin, et. al 2000). The research team followed rigorous procedures of random sampling, did social mapping to define sampling frames and did ethnographic fieldwork which established a network of contacts within the communities. The interviews were conducted by Mexican American fieldworkers who were known and trusted by the respondents, close in age but slightly older. Those interviews made available to this researcher were based on rigid protocols which often limited responses to questions, thereby limiting these observations about the nature of their linguistic practices. Some iconic characteristics of their argot emerge in their interviews, however, as will be demonstrated. The excerpts that will be presented here are representative of the longer stretches of discourse produced by some of these respondents in answer to questions which allowed for elaboration.

Spanish is used as the primary language of the first excerpt, and Spanish and English are both used in the second. The last excerpt reflects the language shift to English that is typical of younger generations of ethnic Chicanos. While the transmission of the gitano caló speech style to Chicano youths via Spanish and bilingual SpanishEnglish discourse is still of primary interest here, not 
all Hispanic gangs have remained fluent in Spanish. The speech style used by English-dominant Hispanic youths illustrates the influence of African American Vernacular English (AAVE). The linguistic parallels between caló and the youth argot found in AAVE are striking, although not surprising. In the urban culture of the latter, as in the Chicano group, there is a positive value placed on verbal performance, including word play (e.g., rapping, playing the dozens, sounding), the invention of neologisms through word creation strategies, and the appropriation of a common word to serve another meaning (e.g., "fresh" and "bad" as positive terms). The same factors that explain the in-group speech style of Chicano homeboys also appear to be held in common by African American gang youths: socio-economic marginalization, a need for an identity outside of the general American mainstream, and an internal standard of ethics, among others. In short, despite having arisen from different linguistic roots, their linguistic similarities can be linked to their sharing similar communities of practice. The English-dominant Chicanos who practice a "homeboy" lifestyle appear to have appropriated AAVE street talk, which can be considered the English language version of the caló speech style. Subsequent sections of the present study present three excerpts: one from a predominantly Spanish-language interview, then a bilingual interview, and finally a predominantly English-language interview. Each will show a different level of loyalty to Spanish but all three illustrate a connection with the caló of the Spanish gitanos. The third will also show an alignment with African American gang youths' communities of practice in their speech style.

\section{Excerpt \#1 - Alex, Laredo, age 14}

The first excerpt is from a fourteen-year-old gang member, pseudonym "Alex," from Laredo, Texas, a city on the Mexican border which is more Spanish-language retentive than San Antonio. He says that he was ten 
years old when he was inducted into the gang:

INT: Otro pleito que haigas tenido. OKAY* ${ }^{*}$ porque 'orita me dijiste que había diez- (ANOTHER FIGHT YOU HAD. OKAY, BECAUSE JUST NOW YOU SAID YOU HAD TEN-)

ALEX: Sí. (YES)

INT: OKAY. So piensa en otro que haigas tenido. ¿En dónde? (OKAY. SO THINK ABOUT ANOTHER ONE YOU HAD. WHERE?)

ALEX: Ajuera de la escuela. (OUTSIDE THE SCHOOL.)

INT: OKAY. ¿Con quién? (OKAY. WITH WHOM?)

ALEX: Con un muchachillón. Era RANK RELATED [sic]. (WITH A BOY. IT WAS GANG RELATED.)

INT: OKAY. ¿Qué-- ¿Cómo comenzó? (OKAY. HOW DID IT BEGAN?)

ALEX: Le comenzó hacer pedo a mi ruca. (HE BEGAN TO MESS WITH MY GIRL)

INT: OKAY. Este, ¿Y cuándo pasó esto? ¿Hace cómo qué tanto? (OKAY. UH, AND WHEN DID THIS HAPPEN? HOW LONG AGO?)

ALEX: Hace . . . TWO WEEKS. (IT WAS TWO WEEKS AGO)

INT: OKAY ¿Y andabas loco tú? (OKAY. AND YOU WERE HIGH?)

ALEX: NO. Ni él. (NO, HIM NEITHER.)

[*In these discourse segments, English is shown in ALL CAPS as are translations into English. Typical slang or argot words and phrases are underlined. Nonstandard Spanish forms are typical of this regional dialect and are represented by means of nonstandard orthography.]

The dialogue continues in this vein, but Alex continues to use the normal vocabulary and pronunciation typical of working class Spanish. In this excerpt, only a few words and expressions are typical of caló speech. The first 
is hacer pedo, literally, "make a fart" but interpreted metaphorically as meaning "to mess with". The next is ruca, literally meaning "old lady" and by semantic extension meaning "woman, girl". Both could be classified as jerga mejicana or contemporary Mexican slang, but both are slightly vulgar renderings of meanings that could be more politely stated. The metaphor loco "crazy" for "high" is also a semantic extension that is part of common slang. Other than these few expressions, this hour-long interview did not exhibit vocabulary and wordplay typical of Mexican American caló.

\section{Excerpt \#2 - Carlos, Laredo, age 16}

The second excerpt is one in which switches between English and Spanish are frequent. Carlos is also from Laredo and is sixteen years old. Both he and the interviewer, a second-generation speaker, engage in the switching.

INT ¿Y qué era? Bironga, liquor- (AND WHAT WAS IT? BEER, LIQUOR, --)

CAR: Bironga, mota, chiva, soda. Traía de todo. (BEER, GRASS, COCAINE, SODA. THERE WAS EVERYTHING.)

INT: OKAY. SO THAT THEY WERE CHICKS, eran mostly, verdad? CHICKS que se juntan con ustedes, or eran las GIRLFRIENDS? (THEY WERE GIRLS, MOSTLY, RIGHT? GIRLS THAT GET TOGETHER WITH YOU, OR WERE THEY THE GIRLFRIENDS?)

CAR: Eran rucas que se juntan y unas eran sus camaradas. (THEY WERE GIRLS WHO GET TOGETHER AND SOME WERE THEIR FRIENDS.) Eran las GIRLFRIENDS de los vatos. (THEY WERE THE GIRLFRIENDS OF THE DUDES.)

INT: WHEN WAS THE LAST TIME YOU WERE ALL JUST HANGING OUT, JUST KICKING?

CAR: Hace como-También unos THREE AND A 
HALF MONTHS, algo... (IT WAS ABOUT THREE AND A HALF MONTHS AGO, SOMETHING...)

In this excerpt some of the characteristic lexicon of traditional caló is evident. The extensive code-switching for these speakers appears to reflect a community norm in South Texas (Garcia 2009). Below is a list of the words that are traditonal Pachuco or Mexico City caló as they fit into a taxonomy of caló speech (for more see Garcia 2005):

\begin{tabular}{l|l|l|}
\multicolumn{1}{l}{ Word } & \multicolumn{1}{l}{ Category } & \multicolumn{1}{l}{ Explanation } \\
\hline bironga & neologism/anglicism & Play on English "beer" + -onga \\
\hline mota, chiva & common slang & Slang for "marijuana" and "cocaine" \\
\hline rucas & slang/pejorative reference & Pachuco slang for "girl", lit. "old lady" \\
\hline camaradas & slang/sem. extension & Pachuco slang, "comrades" for "friends" \\
\hline vato/bato & gypsy origin & "man, dude", from Sanskrit "old, great" \\
\hline
\end{tabular}

It can be seen from this wordlist that plays on words, metaphor, and slang (in the taboo semantic field of drugs) are still very much a part of Chicano youth caló. To be noted in particular is the word vato (also spelled bato), which originated as part of the caló jergal of the gypsies in the late nineteenth century (Salillas 1896). This word is still found in the slang of Spain today albeit with a different meaning, "father, old man", attesting to the persistence of the lexicon of this type of ritualized speech.

\section{Excerpt \# 3 - Raymond, San Antonio, age 16}

The final excerpt is from an interview conducted in English in San Antonio in which the speaker is clearly English-dominant. Raymond was born in San Antonio, is sixteen years old, the son of Mexican immigrants. Although he is second-generation, he produces very little Spanish words emblematic of his Hispanic identity. The few that he produced in his interview, but are not used in the excerpted passage, included: chingos de, meaning "fucking lots of" and chavalón/a for "boy/girl," of gypsy 
origin, from Sanskrit chaval' "young goat". This excerpt illustrates the extensive use of slang from African American Vernacular English (AAVE) and street culture which seems to have replaced the Spanish-based caló of earlier generations. The AAVE street slang is underlined.

INT: Can you describe to me the last time you were partying? Like, you know, full-time partying?

RAY It was this Thursday with my homeboy. My homeboy's Dad, it was his birthday. We had the limo, we had the limo that we have and then we had rented another limo. No, it wasn't on Thursday. My bad. It was on a Sunday 'cause we had gone to Military. We went to Military [Rd] when we went to the Brack [Brackenridge Park] in the limo. Everybody was freaking out, 'cause our limo an' shit, it bombs, you know, "Boom, boom, boom." //Uh-huh//* An' shit, // $\mathrm{Cool} / /^{*}$ you know. It was bad-ass. We was just jammin' in there. And then when-- The other one, I was in the other one, the one that we rented. It was bigger and shit. It was a long-assed one. I was hanging out through the top and (it was like) "Nah, nah, nah. We're gonna get stopped." "I don't give a fuck. That's what you (got) paid for, right, mother-fucker? And they were like, saying a lot of Halleys. "What's up, motherfuckers? (And I say), "I'm like the (town) an' everything an' shit. I was all fucked up."

["Backslashes indicate the interviewer's interspersed comments, known as back-channeling. Parentheses indicate phrases that are not clear.]

The street slang used by Raymond has many things in common with what has been observed for Spanish caló, 
such as neologisms and other innovative expressions characteristic of youth culture. The most salient expression of youth argot in this excerpt is the repeated use of taboo words that represent the teen's defiance of adult social norms. The fact that this teen's language reflects AAVE youth culture may simply be a byproduct of the pervasive influence of African-American culture on North American youth in general rather than of direct contact (see Fought 2006, 75). San Antonio has a very small percentage of this racial group in the city, less than $8 \%$, whose neighborhoods are geographically segregated from the Hispanic parts of town. It appears that language shift to English in this community because of its distance from the Mexican border and low incidence of recent Spanish-speaking immigrants (Garcia 2003) has meant that speaking Spanish and caló use may not constitute an important behavior in the community of practice of Chicano gang youths in the San Antonio of the twentyfirst century.

\section{Conclusions}

The similarities between gypsy caló, Mexican American Pachuco speech, and contemporary Chicano youth group slang are striking, considering their previously mentioned geographic and diachronic separation in space and time. Moreover, having traced their probable historical connection and their participation in similar communities of practice, I have proposed here that their membership in similar communities of practice has been a mechanism for the transmission and continuity of this Spanish-language speech style across the centuries and across an ocean. The iconic function of the shared speech style known as caló or Pachuco talk links these various communities in marking their marginalization, their perceived limited social mobility, and in-group identity. The real-life Pachuco of the 1940's appears to have become a cultural icon for many Mexican American youths of that period, 
whose adoption of the speech style was a means to express their defiance of convention and their unique bilingual identity. Later generations extended some of the lexicon of the Pachuco's argot to everyday use in the community, but the persistence of a secret code in bilingual youth gangs attests to the need for such a code in these communities of practice. The corresponding English-based speech style of some modern-day Chicano "homeboys" which absorb the in-group lexicon and expressions typical of African American street vernaculars is no less defiant of the norms of "proper" English than its predecessor. Although without the Spanish base it may no longer, strictly speaking, be called caló, the ingroup speech style of these youths appears to follow in the traditions of its gypsy and Pachuco predecessors in its alignment with a similar community of practice.

Currently language shift to English for the younger generations may be creating schisms across the community based on language dominance and linguistic allegiance, as well as social factors. New waves of immigrants from Mexico and other Spanish-speaking countries are creating their own speech communities. Undoubtedly, they still employ a jerga, 'slang', and quite possibly an argot that is descendant of gypsy caló. The excerpts from these three interviews show that Chicano youth in South Texas have repertoires that range from monolingual Spanish to extensive code-switching or to monolingual English with strong influence from AAVE. While some of the vocabulary used reflects the traditional Spanish caló of the Pachuco days, the fact that its use is limited to only a few words indicates that in some of these communities a language shift to English appears to be underway. Although the speech samples obtained did not reflect the most informal register of these youths, it is significant that they showed characteristics of the type of argot used in the past in similar communities of practice. As in the past, not all youths in marginalized communities are 
defiant of societal sanctions, but those who continue to assert their "otherness" today appear to reaffirm their identity by means of a speech style handed down over the centuries.

\section{Appendix A: Gitano caló jergal [Gypsy jail slang]}

The following discourse samples were said by a young man incarcerated in Madrid, cited in Salillas (1896). The translations to English are those of the present author.

Sample 1: Un robo [A robbery]

Vamos a chalar á un dron á randar porque chala un busnó con mucho sonague; va montado en una berda. [We're going to go down the road for a robbery because there is a stranger there with a lot of dough in a wagon.] (242)

chalar=marchar, caminar; dron=camino; randar=robar; busnó=estraño, paleto; sonague $(\mathrm{N})=$ oro; berda=carro. (Salillas 1896, 242)

Sample 2: Un engaño [A deception]

Vamos a llevarle a ese eray un gras nililo, porque tenela muchos jallares y vamos a engañisarle. [We're going to take that gentleman a crazy horse, because he has a lot of riches and we're going to trick him.](242)

eray=caballero; gras=caballo, nililo=loco; tenelar, engañisarle=alargamientos de los verbos tener y engañar; jallares o jayeres=hacienda, fortuna. (Salillas 1896, 242-3)

Sample 3: Una seducción [A seduction]

¿Tú te camelas aviyar con á manguis? A manguis tenelo muchos jayeres para diñártelos a tuguis para que jalleles $\mathrm{y}$ vistisieres. Comprendo que tenelas otro manus, pero yo tenelo más pelés que él y se la voy á quitizarar. [Do you want to come with me? I have a lot of money to give you for you to spend and dress well. I understand that you have another man, but I have more balls than he and I am going to take you away from him.] (243) 
camelar=querer; abillar=venir; manguis=conmigo; jayeres=dinero; diñar=dar; tuguis=ti; jalleles=cobres; vistisieres=vistas; manus=hombre; pelés=cojones; quitizarar=quitar. (Salillas 1986, 242-3)

The themes in these discourse samples are in keeping with the illicit activities of criminals. Although each is brief, there are enough Spanish function words and some content words that allow a speaker of Spanish to understand it somewhat, but not completely. The ingroup agenda of hiding meaning is achieved by using words from germania (the past-generation's criminal jargon) and by neologisms, literally "new words", derived from wordplay in Spanish and Romany.

\section{APPENDIX B: Pachuco caló [The Pachuco argot]}

By way of illustrating the Pachuco caló of the 1940's-'60's, the following dialogue is reported to be from an authentic tape-recording made in El Paso, Texas, transcribed and published in Sánchez (1994 [1984],129-132). Much of the discourse is accessible to modern day bilingual Chicano/as raised in barrios where Mexican Spanish is spoken. Recent immigrants from Mexico may recognize it as how the older generation spoke. The meanings of the words in bold are taken, in part, from Sanchez' word lists in the same source. The underlined words appear in the caló jergal 'prison slang' dictionary in Salillas (1896). The translations to English are those of the present author.

\section{El Paso Caló Dialogue}

--Guacha, ¿por qué no me alivianas con un aventón y me dejas en el chante? Y mientras que vas por el Chente, yo tiro claváo, me rastío la greña y me entacucho. Te trais al Chenete a mi cantón y le digo a la jefa que nos aliviane con un calmante porque a mí ya me trai la jaspia y quiero refinar. Le dices al Chente que 'stoy invitáo a un borlo y pa que se desaguite el vato le digo a mi guisa que le consiga una jainita para irnos a borlotear todos. [Look, why don't you help me out with a ride and leave me at my place? And while you go for Vince, l'll take a bath, comb my hair, and get dressed. You bring Vince back to my shack and I'll ask my Mom to give us us a meal because I'm dying of hunger and I've got to eat. Tell Vince that I'm invited to a dance and so that the dude can get out of the dumps. l'll tell my girlfriend to get him a girl so we can all go out partying.] 
guachar=mirar; alivianar=ayudar; aventón=llevar en auto; chante=casa; tiro claváo=me baño; rastrío la greña=me peino (el pelo); me entacucho=me visto; cantón=casa; jefa=mamá; calmante=algo de comer; jaspia=hambre; refinar=comer; borlo=baile, fiesta; desaguite=se ponga alegre; vato=muchacho; guisa=chica, muchacha; jainita=chica, muchacha

--Pos, 'stá de aquella la idea pero, pos tú sabes que el Chente va andar muy quebradón porque acaba . . . va acabar de desafanar y no trai garra de aquella. ¿Cómo la ves? [Well, it's a terrific idea but, well you know that Vincent is going to be very broke because he. . . he'll be just out of jail and he doesn't have good clothes. What do you think?]

--O, dile que no se aguite. Le dices que no hay fijón por la feria y si necesita garra, yo le empresto pantas, lisa, taiya, carlangos, calcos, y hasta calcetas si quiere. Sirve que cuando 'stemos refinando quiero que oiga unas rolas que aparé ora, ¿ves? 'Tan a todo guelo. ¡Tú sabes las songas que hay orita 'tan a todo guelo! [Oh, tell him not to feel bad. Tell him that it doesn't matter about the dough and if he needs clothes l'll lend him some pants, a shirt, a tie, a jacket, shoes and even socks if he wants. It's just that while we're eating I want him to hear some records that I bought today, see? They're totally awesome. You know that the songs that are out today are totally awesome!]

de aquella=magnífico; quebradón=sin dinero; desafanar=salir de la cárcel; garra=ropa; aguitarse=deprimirse; no hay fijón=no importa; feria=dinero; emprestar=prestar; pantas=pantalones; lisa=camisa; taiya=corbata; carlangos=chaqueta; calcos=zapatos; calcetas= calcetines; refinando=comiendo; rolas=discos; aparar=comprar; songas=canciones;

a todo guelo (vuelo)=fantástico.

--Orale pues. 'Tonces ahí te guacho en tu cantón. Pero también le dices a la jefita que me aliviane con un refinazo, ¿eh? Y que no se le olvide los biroles, porque tú sabes como me cain de aquéllas los biroles, ¿eh? 'Tá de aquella. [Sounds good. So then I'll see you at your place. But also ask your Mom to give me something to eat, huh? And don't let her forget the beans, because you know how I love beans, huh? They're awesome.]

órale, pues=de acuerdo; biroles=frijoles

--Simón que yes, ese. 'Tonces aquí te ... ahí te calmo después que me dejes, ¿eh? !'Tá de aquella! [Sure thing, guy. Then here ... I’ll 
see you there after you drop me off, huh? Terrific idea!]

Simón que yes=claro que sí, hombre; te calmo=te veo

\section{Works Cited}

Alarcón, Alejandro. El Habla popular de los jóvenes en la ciudad de México. México: B. Costa-Amic Editor, 1978.

Barker, George C. "Pachuco: An American Spanish Argot and Its Social Function in Tucson, Arizona." In El Lenguaje de los Chicanos, edited by Eduardo Hernández-Chávez, Andrew D. Cohen and Anthony F. Beltramo, 183-201. Arlington, VA: Center for Applied Linguistics, 1975.

Borrow, George H. The Zincali, or An Account of the Gypsies of Spain ( $3^{\text {rd }}$ ed). London: J. Murray, 1843.

Chaliand, Gérard and Jean Pierre Ragean. The Penguin Atlas of Diasporas. NY: Viking Penguin, 1995.

Chambers, J.K. Sociolinguistic Theory. Cambridge: Blackwell, 1995.

Cipas, Juan. Vocabulario popular malagueño (2nda ed.). Málaga: Librería Ibérica.

Coltharp, Lurline. The Tongue of the Tirilones. University, Alabama: University of Alabama Press, 1965.

Coupland, Nikolas. "Language, Situation, and the Relational SelfMeaning Dichotomy." In Style and Sociolinguistic Variation, edited by Penelope Eckert and John Rickford, 185-210. Cambridge: CambridgeUniversity Press, 2001.

Eckert, Penelope. "Style and Social Meaning." In Style and Social Variation, edited by Penelope Eckert and John R. Rickford, 119-126. Cambridge: Cambridge University Press, 2001.

Eckert, Penelope and Sally McConnell-Ginet. "Constructing Meaning, Constructing Selves: Snapshots of Language, Gender, and Class from Belten High." In Gender Articulated, edited by Kira Hall and Mary Bucholtz, 469-507. New York: Routledge, 1995. 
--.. "Communities of Practice: Where Language, Gender, and Power all Live." In Locating Power: Proceedings of the Second Berkeley Women and Language Conference, edited by Kira Hall, Mary Bucholtz and Birch Moonwomon, 89-99. Berkeley: Women and Language Group, 1992.

Fought, Carmen. Language and Ethnicity. New York: Cambridge University Press, 2006.

Garcia, MaryEllen. "Code-Switching and Discourse Style in a Chicano Community." In Español en Estados Unidos y Otros Contextos de Contacto, edited by Manel Lacorte and Jennifer Leeman, 137-156. Madrid: Iberoamericana, 2009.

--.. “Influences of Gypsy Caló on Spanish Dialects." Hispania 88:4, (December 2005): 800-812.

---. 2004. "Marginalization and the Voice of Hispanic Youth." Paper presented at: Voices of the Other in Educational and Civic Discourses: A Research Symposium, University of Texas at San Antonio, April 1, 2004.

-.-. 2003. "The Caló of Hispanic Youth." Paper presented at Fourth International Symposium on Bilingualism, University of Arizona, April 30 - May 1,2003.

Galindo, Leticia. "Caló and Taboo Language Use among Chicanas." In Speaking Chicana: Voice, Power, and Identity. Leticia Galindo and Maria Dolores Gonzalez. Tucson: The University of Arizona Press, 1999.

Guerrero, Lalo and Sherilyn Meece Mentes. Lalo - My Life and Music. Tucson, AZ: University of Arizona Press, 2002.

Irvine, Judith T. "'Style' as Distinctiveness: The Culture and Ideology of Linguistic Differentiation. In Style and Sociolinguistic Variation, edited by Penelope Eckert amd John R. Rickford, 21-43. New York: Cambridge University Press, 2001.

McWilliams, Carey. North from Mexico. New York: J.B. Lippincott 1968 [1949].

Milroy, Leslie. Observing and Analysing Natural Language. Oxford: Blackwell, 1987. 
Moore, Joan. Going Down to the Barrio: Homeboys and Homegirls in Change. Philadelphia: Temple University Press, 1991.

Oliver, Juan Manuel. Diccionario del argot. Madrid: SENAE, 1987.

Pagan, Eduardo Obregon. Sleepy Lagoon: The Politics of Youth and Race in Wartime Los Angeles, 1940-1945. Ann Arbor, Mich.: UMI Dissertation Services, 1996.

Salillas, Rafael. El delincuente español: El lenguaje. Madrid: Suárez. 1896.

Sánchez, Rosaura. Chicano Discourse: Socio-Historic Perspectives. Houston, TX: Arte Público Press [Rowley, MA: Newbury House] 1994 [1984].

Stewart, Stuart. The Spanish Gitano: Echoes of an Uneasy Simbiosis. MA thesis, Modern Languages, Texas A \& M University, 1992.

Vigil, Diego. Barrio Gangs. Austin, TX: University of Texas Press, 1988.

Valdez, Avelardo and Charles D. Kaplan. "Reducing selection bias in the use of focus groups to investigate hidden populations: The Case of Mexican-American gang members from South Texas." In Drugs and Society. The Haworth Press, Inc, 1999.

Wagner, Max von Leopold. "Ein mexikanisch-americanischer Argot: das Pachuco. " Romanistisches Jahrbuch 6 (1955), 237-266.

Webb, John Terrance. "Mexican-American caló and Standard Mexican Spanish." In Spanish in the United States: Sociolinguistic Aspects, edited by Jon Amastae and Lucía Elías-Olivares, 121-131. New York: Cambridge University Press, 1982.

-.-. A Lexical Study of Caló and non-Standard Spanish in the Southwest. U.C. Berkeley dissertation. Ann Arbor, Michigan: UMI Dissertation Services, 1976.

Yin, Zenong, Avelardo Valdez, Alberto G. Mata, Jr., and Charles Kaplan. "Developing a Field-Intensive Methodology for Generating a Randomized Sample for Gang Research." In Free Inquiry - Special Issue: Gangs, Drugs, \& Violence, 28:1 (2000): 81-90. 